\title{
The ammonoid recovery after the end-Permian mass extinction: Evidence from the Iran-Transcaucasia area, Siberia, Primorye, and Kazakhstan
}

Yuri D. Zakharov and Nasrin Mousavi Abnavi

Acta Palaeontologica Polonica 58 (1), 2013: 127-147 doi: http://dx.doi.org/10.4202/app.2011.0054

Investigations of the Upper Permian strata in the Iran-Transcaucasia resulted in identification of 32 ammonoid genera. The majority of ammonoids in this collection belong to the order Ceratitida (75\%). Among Dzhulfian ceratitid ammonoids representatives of the family Araxoceratidae (Otoceratoidea) are most abundant. The assemblage structure changed radically during latest Permian (Dorashamian) time, bringing a domination of the family Dzhulfitidae. The Induan (Lower Triassic) succession in the Verkhoyansk area provided a few groups of ammonoids which are Palaeozoic in type: families Episageceratidae (Episageceras), Xenodiscidae (Aldanoceras and Metophiceras ), and Dzhulfitidae (Tompophiceras) and superfamily Otoceratoidea (Otoceras and Vavilovites ). It demonstrates the survival of ammonoids belonging to these groups the Permian-Triassic (P-T) boundary extinction event and their quick migration to the vast areas of higher latitudes (together with some representatives of the Mesozoic-type families). Induan-Olenekian ammonoid successions in South Primorye, Mangyshlak, and Arctic Siberia illustrate the high rate of Early Triassic ammonoid recovery in both the Tethys and the Boreal realm. New ammonoid taxa are described: Proptychitina subordo nov., Ussuritina subordo nov., Subbalhaeceras shigetai gen. and sp. nov.

(Flemingitidae), Mesohedenstroemia olgae sp. nov. (Hedenstrormiidae), and Inyoites sedini sp. nov. (Inyoitidae).

Key words: Ammonoidea, recovery, Permian, Triassic, Russia, Azerbaijan, Kazakhstan, Iran.

Yuri D. Zakharov [yurizakh@mail ru], Far Eastern Geological Institute, Far Eastern Branch, Russian Academy of Sciences, Stoletiya Prospect 159, Vladivostok, 690022 Russia; Nasrin Mousavi Abnavi [nm_geologist80@yahoo.com], Isphahan University, Department of Geology, Isphahan, Iran. 
This is an open-access article distributed under the terms of the Creative Commons

Attribution License (for details please see creativecommons.org), which permits unrestricted use, distribution, and reproduction in any medium, provided the original author and source are credited.

FoF 